\title{
Geoelectrohydraulic investigation of the surficial aquifer units and corrosivity in parts of Uyo L. G. A., Akwa Ibom State, Southern Nigeria
}

\author{
Johnson C. Ibuot $^{1} \cdot$ Daniel N. Obiora ${ }^{1} \cdot \operatorname{Moses~M.~M.~}$ Ekpa $^{2} \cdot$ Doris O. Okoroh $^{2}$
}

Received: 2 September 2017 / Accepted: 16 October 2017/Published online: 28 October 2017

(c) The Author(s) 2017. This article is an open access publication

\begin{abstract}
This study was carried out employing vertical electrical sounding (VES) with Schlumberger electrode configuration. The objectives were to investigate the distribution of the geohydraulic parameters and the corrosivity of the aquifer layer within the study area. The sand-tocoarse grain sands aquifer have resistivity ranging from 8.1 to $2204 \Omega \mathrm{m}$, while the thickness ranged from 7.4 to $55.3 \mathrm{~m}$. These parameters were used in computing the geohydraulic parameters. Hydraulic conductivity was estimated using the Heigold equation, and its values ranged from 1.42 to $54.90 \mathrm{~m} /$ day. Estimated hydraulic conductivity values were employed in determining the aquifer transmissivity which ranged from 11.28 to $812.00 \mathrm{~m}^{2} /$ day, fractional porosities ranged from 0.0351 to 0.0598 . The longitudinarl conductance also varies from 0.01 to $1.83 \Omega^{-1}$. The contour plots generated from the SURFER software package show the variation of these parameters. The ranges of these estimated parameters indicate variation in grain sizes, magnitude of pore sizes and facies changes. The corrosivity rating indicates that most of the VES points were practically non-corrosive.
\end{abstract}

Keywords Aquifer - Geohydraulic properties . Transmissivity $\cdot$ Hydraulic conductivity $\cdot$ Porosity

Johnson C. Ibuot

johnson.ibuot@unn.edu.ng

1 Department of Physics and Astronomy, University of Nigeria, Nsukka, Nigeria

2 Department of Physics, School of Science Education, Federal College of Education (Technical), Omoku, Rivers State, Nigeria

\section{Introduction}

Groundwater is important in all aspect of life. It is the major source of drinking water and is useful in the agricultural and industrial sectors, and a good knowledge of the aquifer repositories is a concern for its sustainable and effective use (Edet and Worden 2009; Evans et al. 2010; George et al. 2015a, 2016a, 2017a; Obiora et al. 2015). Since the aquifer in the coastal regions is shallow, residents drilling for potable groundwater do not care about getting geophysical information about the area before drilling. These have led to wildcat drilling across the area, which has resulted to boreholes failure and in some cases the quality of the groundwater extracted may not be good.

Geophysical investigation of the subsurface to delineate groundwater resource have increased over the years, this is due to the advance in technology which have improved the interpretation and modeling of the parameters. The lithotextural characteristics, pore-water conductivity and fluid saturation of hydrogeological unit affect electrical conductivity of the subsurface geomaterials (Ibanga and George 2016).

Different physical parameters are distributed in the earth subsurface and the use of non-destructive and non-invasive geophysical methods can help provide information about these parameters. It is an indirect method that predicts a model of the subsurface as a result of interpreting the physical parameters. The electrical resistivity method though may be plagued with ambiguities and uncertainties in interpretation, provides an economical and reliable means to identify and delineate the subsurface characteristics/properties through the measurement of apparent resistivity (Batayneh 2009; Muchingami et al. 2012; Ebong et al. 2014; Okiongbo and Mebine 2015). 
The flow and recharge of the aquifer repositories unit is affected by the aquifer characteristics and the knowledge of these parameters such as hydraulic conductivity, transmissivity, porosity, formation factor and tortuosity is necessary to describe the hydrogeological units quantitatively. There is need for adequate information about the pore properties and the interrelationship with other aquifer parameters (George et al. 2015b). Electrical and hydraulic conductivity are functions of the pore size and have different sensitivity to the characteristic pore size (George et al. 2014). The subsurface is characterized by pores linking the formation particles and a good understanding of the pore properties gives idea about fluid movement in the subsurface (George et al. 2015a). Porosity which measures the amount of pore spaces in a formation is given by the relation:

Porosity $(\phi)=\frac{\text { volume of pores }}{\text { total rock volume }}$

Porosity is a formation property whose spatial variability depends on several factors like density, clay contents, tortuosity, hydraulic conductivity (Jackson et al. 1978). Induration or lithification of sedimentary formation leads to significant deviations in pore geometry system (George et al. 2016a). Archie's law summarized the occurrence of groundwater in rocks and soil, and gave the relationship between porosity, bulk resistivity and water resistivity in Eq. 2;

$\rho=a \rho_{\mathrm{w}} \phi^{-m}$

where $\rho$ is the bulk resistivity, $\rho_{\mathrm{w}}$ is water resistivity, $a$ and $m$ are the pore geometric factor and cementation factor, respectively (Keller and Frischnecht 1966). Cementation factor is fixed but varies with formation lithostratigraphy, permeability dependent factors and geologic age of geomaterials (Archie 1942; Keller 1982) according to different tabulated values. The maximum amount of information about pore structure is embedded in transport processes. Aquifer hydraulic conductivity $(K)$ is the ease with which water can move through an aquifer. It varies in a geological unit over relatively short distances, particularly in fractured rock aquifer. The $K$-values are important as they help in differentiation of aquifer bodies and their yield. According to Heigold et al. (1979), the values of $K$ for a similar formation can be estimated using the relation below;

$K=3.86 .40 R_{\mathrm{rw}}^{-.93283}$

where $R_{\mathrm{rw}}$ is the resistivity of the aquifer.

Transmissivity ( $\mathrm{Tr}$ ) is the ability of the aquifer to transmit groundwater throughout its entire saturated thickness. It is a measure of the rate at which groundwater can flow through an aquifer section of unit width under a hydraulic gradient. Niwas and Singhal (1981) established an analytical relationship between transmissivity and transverse resistance, and also between transmissivity and longitudinal conductance. The discharge $(Q)$ of fluid according to Darcy's law is given as

$Q=K I A$

But from Ohm's law:

$J=\sigma E$

where $\sigma$ is electrical conductivity, $K$ is the hydraulic conductivity, $A$ is cross sectional area perpendicular to the direction of flow, $J$ is current density, $E$ is electric field intensity, $I$ is the hydraulic gradient.

From Eqs. 2 and 3, Niwas and Singhal (1981) obtained relationships given as

$T_{\mathrm{r}}=K \sigma T=\frac{K S}{\sigma}=K h$

where $T_{\mathrm{r}}$ is aquifer transmissivity, $T$ is transverse resistance and $\mathrm{S}$ is longitudinal conductance. The longitudinal conductance and transverse resistance ( $S$ and $T$ ) referred to as Dar-Zarrouk parameters and are given as

$S=\frac{h}{\rho}$

$T=h \rho$

where $h$ and $\rho$ are the values of aquifer thickness and resistivity, respectively.

The flow/percolation of fluid in subsurface may be influenced by these parameters which depends on the geometry, nature of grain size, non-uniformity of pore grain orientations and type of pore grains and pore channels and hydraulic pressure (George et al. 2017b). This work employs surface geophysical (resistivity) method to study the aquifer repositories to investigate the relationship between bulk electrical and pore properties of the aquifer repositories in the study area.

\section{Location and geology of the study area}

The study area belongs to the Niger Delta region of Nigeria which is a Cenozoic wave-dominated delta system (Fig. 1). It lies within $5.03^{\circ} \mathrm{N}$ and $5.09^{\circ} \mathrm{N}$ of latitude and $7.41^{\circ} \mathrm{E}$ and $8.10^{\circ} \mathrm{E}$ of longitude in the tropical rain forest belt of Nigeria and form part of the low lying coastal/deltaic plains of the southern Nigeria. The study area belongs to the deltaic marine environment of Cretaceous to recent age (Offodile 1992), comprising Benin formation, which is the most proximal of the three major stratigraphy megasequences of the Niger Delta. It is composed predominantly of continental fluvial deposits that do not extend offshore 


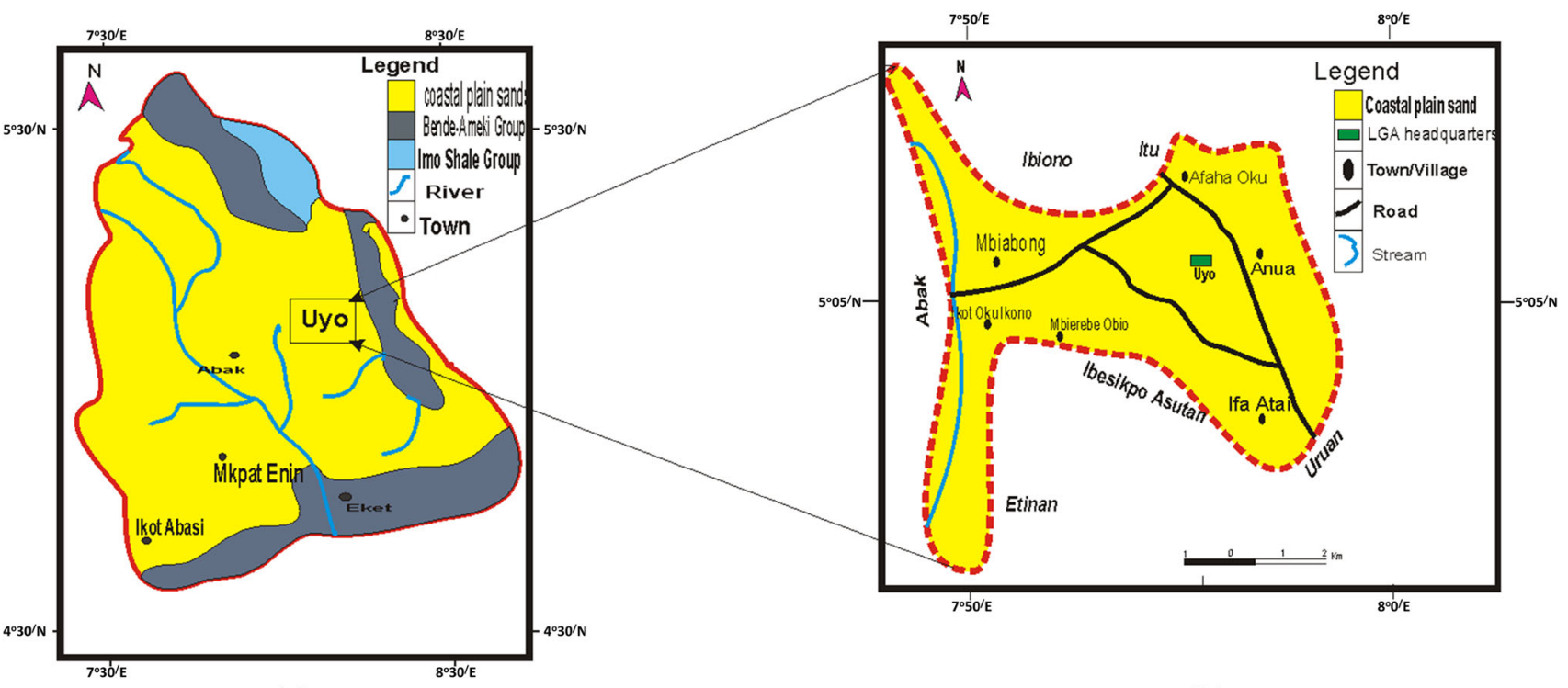

(a)

(b)

Fig. 1 a Sketch geologic map of Akwa Ibom State showing the location of Uyo Local Government Area. b Map of Uyo Local Government Area

into deepwater. The Benin formation is made up of finecoarse-grained lenses of sandstone with abundant calcareous shale. The major water sources of the area are subsurface (boreholes) and surface (streams). The relief of the area is low having elevations of less than $10-50 \mathrm{~m}$ above sea level and is trending in the northward direction (Ugbaja and Edet 2004).

\section{Materials and method}

The geophysical survey was carried out employing Schlumberger electrode configuration for ten vertical electrical sounding (VES) using the IGIS Resistivity meter. The half current electrodes spacing $\left(\frac{A B}{2}\right)$ ranged from 1.0 to $300.0 \mathrm{~m}$, and half potential electrodes spacing $\left(\frac{M N}{2}\right)$ of $0.25-20.0 \mathrm{~m}$. The apparent resistivity $\left(\rho_{\mathrm{a}}\right)$ was computed from the relation;

$\rho_{\mathrm{a}}=K \frac{V}{I}=K \cdot R_{\mathrm{a}}$

where $K$ is the geometric factor and it depends on the electrodes arrangements. $R_{\mathrm{a}}$ is the apparent resistance measured on the field. $K$ is given as

$K=\pi \cdot\left[\frac{\left(\frac{A B}{2}\right)^{2}-\left(\frac{M N}{2}\right)^{2}}{M N}\right]$

In reduction of the VES data to 1D geological models, manual and computer modeling techniques were utilized (Zohdy 1965; Zohdy et al. 1974). Bi-logarithmic graphs were used to plot the computed apparent resistivities and curves were smoothened to remove the effects of lateral heterogeneities and other forms of noisy signatures (Chakravarthi et al. 2007; Akpan et al. 2006). These smoothened curves were curve matched using the master curves and charts (Orellana and Mooney 1966). The computer modeling was done using the WinResist software where the calculated apparent resistivity was used as input parameter and the output was a set of geoelectric curves from where the values of resistivity, thickness and depth of each geoelectric layer were obtained.

\section{Results and discussion}

The analysis of the resistivity survey reveals three to five geoelectric layers with characteristic curves of various types. Table 1 shows the resistivity values of the layers within the maximum current separation, together with their depths and thicknesses. The depths were constrained by borehole lithologic information near VES 3 and VES 9 (Fig. 2). The topmost layer resistivity ranged from $10.2 \Omega \mathrm{m}$ at VES $1-2157.0 \Omega \mathrm{m}$ at VES 12 , with thickness and depth ranging from 0.5 to $5.8 \mathrm{~m}$. The resistivity of this layer is observed to be relatively lower than that of the underlying layers. The resistivity of the second layer ranges from 8.1-5820.0 $\Omega \mathrm{m}$ and the thickness and depth varies from 1.2 to 14.8 and 1.7 to $15.8 \mathrm{~m}$, respectively. The third layer resistivity varies from 23.4 to $2204.0 \Omega \mathrm{m}$, while the thickness ranges from 3.0 to $56.3 \mathrm{~m}$ and the depth ranges from 4.7 to $60.9 \mathrm{~m}$. The fourth layer gives resistivity ranging from 75.0 to 2705 . $50 \Omega \mathrm{m}$ with thickness and 
Table 1 Summary of results of resistivity survey from computer modeling

\begin{tabular}{|c|c|c|c|c|c|c|c|c|c|c|c|c|c|c|c|c|}
\hline \multirow[b]{2}{*}{$\begin{array}{l}\text { VES } \\
\text { stations }\end{array}$} & \multirow[b]{2}{*}{$\begin{array}{l}\text { Longitude } \\
\left({ }^{\circ} \mathrm{E}\right)\end{array}$} & \multirow[b]{2}{*}{$\begin{array}{l}\text { Latitude } \\
\left({ }^{\circ} \mathrm{N}\right)\end{array}$} & \multicolumn{5}{|c|}{ Resistivity $(\Omega \mathrm{m})$} & \multicolumn{4}{|c|}{ Thickness (m) } & \multicolumn{4}{|c|}{ Depth (m) } & \multirow{2}{*}{$\begin{array}{l}\text { Curve } \\
\text { types }\end{array}$} \\
\hline & & & $\rho_{1}$ & $\rho_{2}$ & $\rho_{3}$ & $\rho_{4}$ & $\rho_{5}$ & $h_{1}$ & $h_{2}$ & $h_{3}$ & $h_{4}$ & $d_{1}$ & $d_{2}$ & $d_{3}$ & $d_{4}$ & \\
\hline 1 & 7.9336 & 5.0419 & 10.2 & 18.9 & 23.4 & 82.3 & - & 3.0 & 3.5 & 23.5 & - & 3.0 & 6.5 & 30.0 & - & $\mathrm{AA}$ \\
\hline 2 & 7.9341 & 5.0421 & 11.1 & 65.7 & 31.6 & 198.5 & - & 0.9 & 5.7 & 27.7 & - & 0.9 & 6.6 & 34.3 & - & $\mathrm{KH}$ \\
\hline 3 & 7.9348 & 5.0416 & 156.4 & 800.8 & 407.8 & 1350.1 & - & 1.3 & 9.1 & 47.9 & - & 1.3 & 10.4 & 58.3 & - & $\mathrm{KH}$ \\
\hline 4 & 7.9361 & 5.0435 & 298.2 & 683.1 & 377.2 & 1638.2 & - & 0.7 & 7.2 & 17.4 & - & 0.7 & 7.9 & 25.3 & - & $\mathrm{KH}$ \\
\hline 5 & 7.9343 & 5.0426 & 26.0 & 17.0 & 107.3 & 75.0 & - & 1.6 & 2.9 & 56.3 & - & 1.6 & 4.4 & 60.7 & - & HK \\
\hline 6 & 7.9355 & 5.0418 & 68.2 & 263.0 & 219.0 & 554.6 & - & 1.3 & 7.6 & 37.0 & - & 1.3 & 8.8 & 45.8 & - & $\mathrm{KH}$ \\
\hline 7 & 7.9363 & 5.0438 & 377.0 & 217.0 & 1125.8 & 2705.5 & - & 1.7 & 9.5 & 30.6 & - & 1.7 & 11.2 & 41.8 & - & HA \\
\hline 8 & 7.9359 & 5.0433 & 28.6 & 38.2 & 190.1 & 102.5 & - & 1.0 & 11.4 & 40.9 & - & 1.0 & 12.5 & 53.4 & - & $\mathrm{AA}$ \\
\hline 9 & 7.9356 & 5.0441 & 12.8 & 8.1 & 101.3 & - & - & 1.1 & 14.8 & - & - & 1.1 & 15.8 & - & - & $\mathrm{H}$ \\
\hline 10 & 7.9353 & 5.0436 & 63.0 & 29.6 & 64.7 & 176.5 & - & 2.3 & 10.3 & 42.5 & - & 2.3 & 12.6 & 55.1 & - & HA \\
\hline 11 & 7.9217 & 5.0677 & 261 & 1483 & 1970 & 804 & 332 & 0.5 & 1.2 & 3.0 & 27.9 & 0.5 & 1.7 & 4.7 & 32.6 & KHQ \\
\hline 12 & 7.9035 & 5.0566 & 2157.0 & 524.0 & 1682 & 507.0 & - & 2.0 & 3.3 & 55.3 & - & 2.0 & 5.3 & 60.9 & - & HK \\
\hline 13 & 7.9331 & 5.1058 & 692.0 & 1056 & 5442.0 & 1006.0 & 4747.0 & 0.6 & 4.1 & 14.1 & 33.7 & 0.6 & 4.7 & 18.8 & 91.2 & $\mathrm{AKH}$ \\
\hline 14 & 7.9293 & 5.0858 & 112.0 & 5820.0 & 2204.0 & 1200.0 & - & 5.8 & 9.5 & 30.0 & - & 5.8 & 15.3 & 45.3 & - & KA \\
\hline
\end{tabular}

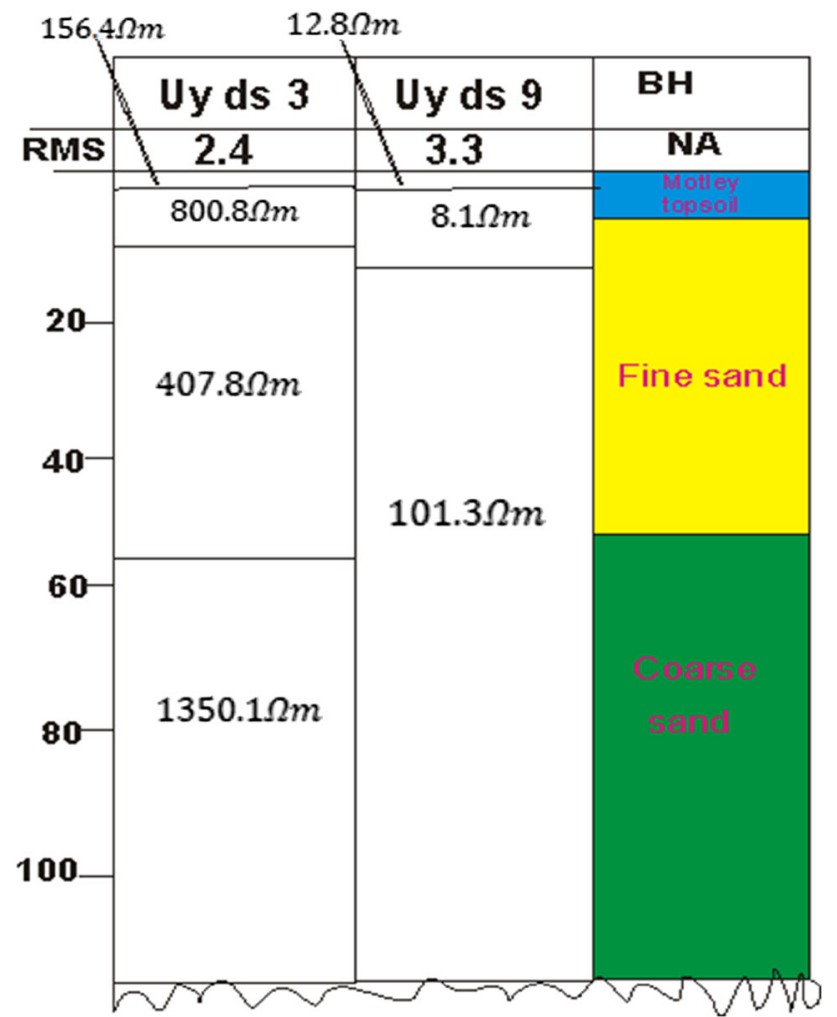

Fig. 2 Borehole lithologic log near VES 3 and VES 9

depth undefined in most of the VES points. The aquifer resistivity ranged from 8.1 to $2204 \Omega \mathrm{m}$, while the thickness ranged from 7.4 to $55.3 \mathrm{~m}$. These parameters were used in estimating the geohydraulic parameters (Table 2). The contour maps were generated using Surfer software package. Figure 3 shows low aquifer resistivity in the southeastern part of the study area, with high values distributed on the other parts of the study area. This may be influenced by the geological materials present in the subsurface (George et al. 2016a, b). In Fig. 4, high aquifer thickness is seen in the western part of the study area.

The distribution of hydraulic conductivity $(K)$ is shown in Fig. 5, where high $K$ is seen in the southeastern part and it varies inversely with the porosity distribution map (Fig. 6). The porosity estimated from Eq. 1 increases from southeast to northwest and is in a reverse direction to the variation of transmissivity. Though some geological materials may be porous but not permeable due to the presence of dead-end pores by the residual argillaceous materials in the tortuous path (George et al. 2015b). Figure 7 is a contour map showing the distribution of aquifer transmissivity, highest value is seen in the southeastern part and decreases towards the northern part of the study area. The map (Fig. 7) closely relates to the hydraulic conductivity map (Fig. 5), the sensitivity of $K$ to facies change affects the distribution of aquifer transmissivity, which depends on $K$ and $h$. The high transmissivity observed in the southern part is an indication of high groundwater reserve in that zone.

In computing the Dar-Zarrouk parameters (longitudinal conductance and transverse resistance), the aquifer resistivity and thickness were used and the variational trends of these parameters are shown in Figs. 8 and 9, respectively. The longitudinal conductance increases in the southeastern 
Table 2 Results of aquifer hydraulic parameters from measured resistivity and thickness of the aquifer layers

\begin{tabular}{|c|c|c|c|c|c|c|c|c|c|c|c|}
\hline VES stations & Long. & Lat. & $\rho_{\mathrm{a}}(\Omega \mathrm{m})$ & $h_{\mathrm{a}}(\mathrm{m})$ & $K$ (m/day) & $\phi(\%)$ & $\begin{array}{l}\text { Fractional } \\
\text { Porosity }\end{array}$ & $\operatorname{Tr}\left(\mathrm{m}^{2} /\right.$ day $)$ & $S\left(\Omega^{-1}\right)$ & $T\left(\Omega \mathrm{m}^{2}\right)$ & $\begin{array}{l}\text { Corrosivity } \\
\text { rating }\end{array}$ \\
\hline VES 1 & 7.9336 & 5.0419 & 23.4 & 23.5 & 20.21 & 28.52 & 0.0351 & 479.58 & 1.00 & 549.90 & $\mathrm{MC}$ \\
\hline VES 2 & 7.9341 & 5.0421 & 31.6 & 27.7 & 15.42 & 28.24 & 0.0354 & 427.13 & 0.88 & 875.32 & $\mathrm{MC}$ \\
\hline VES 3 & 7.9348 & 5.0416 & 407.8 & 47.9 & 1.42 & 25.85 & 0.0387 & 67.96 & 0.12 & $19,533.62$ & $\mathrm{NC}$ \\
\hline VES 4 & 7.9361 & 5.0435 & 377.8 & 7.4 & 1.52 & 25.92 & 0.0386 & 11.28 & 0.02 & 2795.72 & $\mathrm{NC}$ \\
\hline VES 5 & 7.9343 & 5.0426 & 107.3 & 56.3 & 4.93 & 27.10 & 0.0369 & 277.55 & 0.52 & 6040.99 & $\mathrm{SC}$ \\
\hline VES 6 & 7.9355 & 5.0418 & 219.0 & 37.0 & 2.53 & 26.43 & 0.0378 & 93.76 & 0.17 & 8103.00 & $\mathrm{NC}$ \\
\hline VES 7 & 7.9363 & 5.0438 & 1125.8 & 30.6 & 0.55 & 24.90 & 0.0402 & 16.84 & 0.03 & $34,449.48$ & $\mathrm{NC}$ \\
\hline VES 8 & 7.9359 & 5.0433 & 190.1 & 40.9 & 2.89 & 26.56 & 0.0376 & 118.27 & 0.22 & 7775.09 & $\mathrm{NC}$ \\
\hline VES 9 & 7.9356 & 5.0441 & 8.1 & 14.8 & 54.90 & 29.51 & 0.0339 & 812.53 & 1.83 & 119.88 & VSC \\
\hline VES 10 & 7.9353 & 5.0436 & 64.7 & 42.5 & 7.90 & 27.57 & 0.0363 & 335.86 & 0.66 & 2749.75 & $\mathrm{NC}$ \\
\hline VES 11 & 7.9217 & 5.0677 & 804 & 27.9 & 2.60 & 16.72 & 0.0598 & 72.54 & 0.04 & $22,431.60$ & $\mathrm{NC}$ \\
\hline VES 12 & 7.9035 & 5.0566 & 1682 & 55.3 & 3.70 & 18.53 & 0.0540 & 204.61 & 0.03 & $93,014.60$ & $\mathrm{NC}$ \\
\hline VES 13 & 7.9331 & 5.1058 & 1006 & 33.7 & 3.10 & 17.53 & 0.0570 & 104.47 & 0.03 & $33,902.20$ & $\mathrm{NC}$ \\
\hline VES 14 & 7.9293 & 5.0858 & 2204 & 30 & 4.70 & 19.86 & 0.0504 & 141 & 0.01 & $66,120.00$ & $\mathrm{NC}$ \\
\hline
\end{tabular}

Fig. 3 Contour map showing the distribution of aquifer resistivity

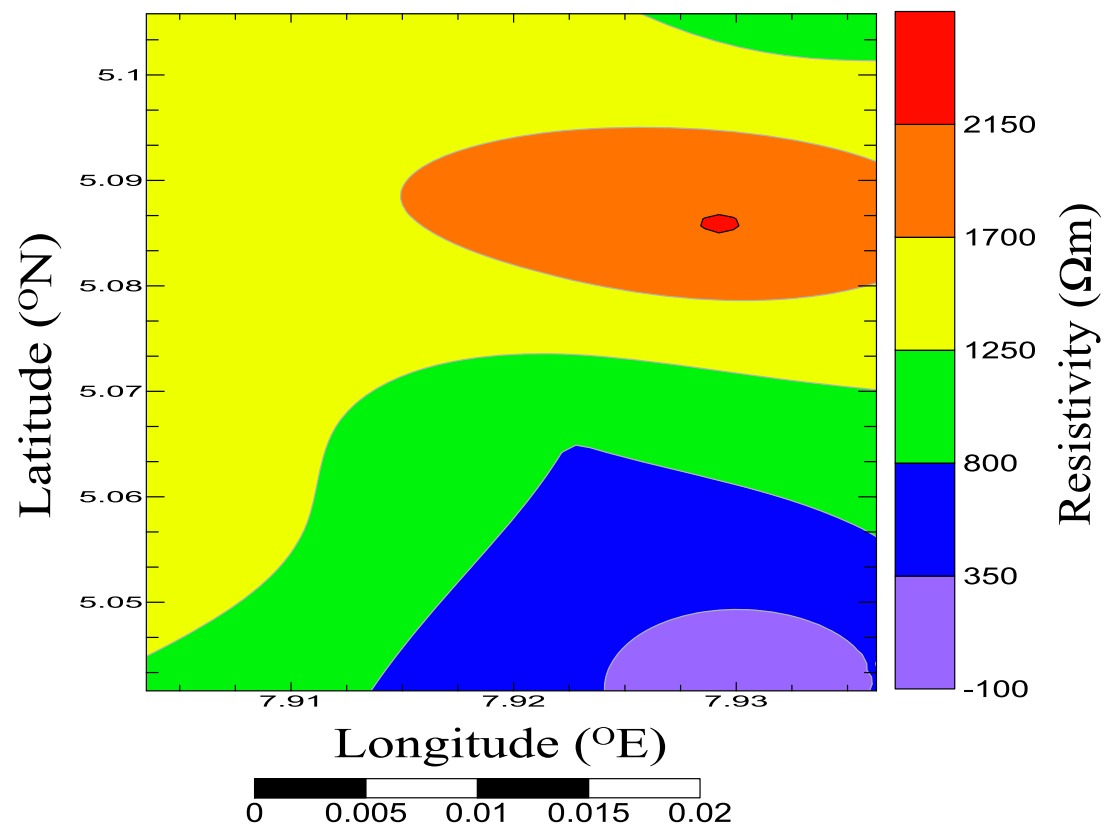

direction while the transverse resistance increases in the north-southeastern direction. The inverse behavior of the Dar-Zarrouk parameters can be seen. The changes in the contour maps may be attributed to the influence of the electric-hydraulic anisotropies, also variations in lithology, grain size, pore shape and pore channels. The corrosivity of the hydrogeological units is determine using Table 3, VES $3,6,7,10,11,12,13$ and 14 suggests the hydrogeological unit to be non-corrosive, it is observed that these VES points have poor protective capacity rating. This non-corrosivity may be attributed to the absence of corrosive substances in the subsurface but the aquifer may polluted by other contaminants such as leachate. VES 1 and 2 were moderately corrosive, VES 5 is slightly corrosive with a moderate protective capacity rating.

\section{Conclusion}

The VES result from the resistivity survey was used to investigate the aquifer layer in the study area. From the result, the resistivity, thickness, depth and lateral extension 
Fig. 4 Contour map showing the variation of thickness

Fig. 5 Contour map showing the variation of hydraulic conductivity
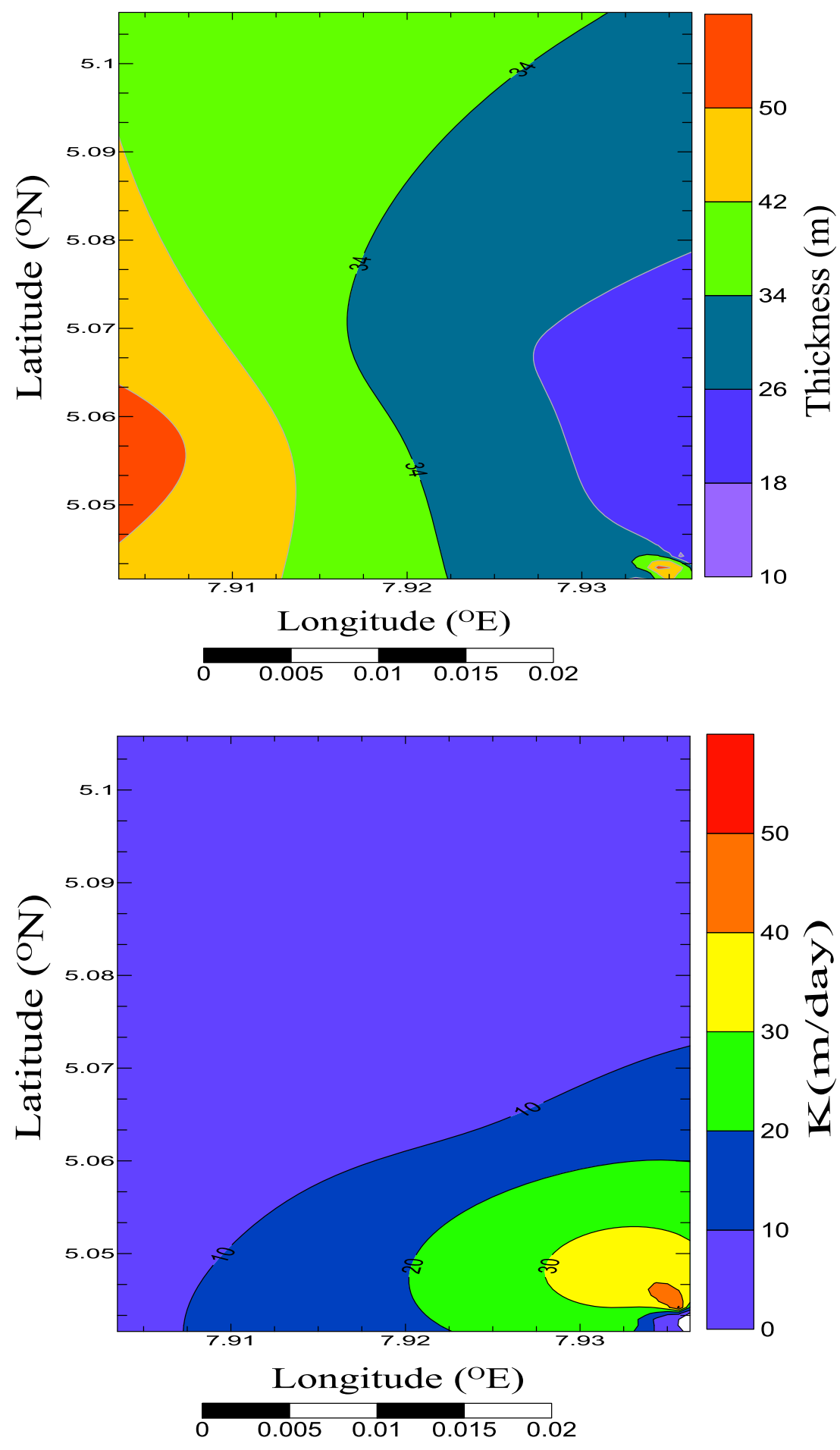
Fig. 6 Contour map showing variation of porosity in the study area

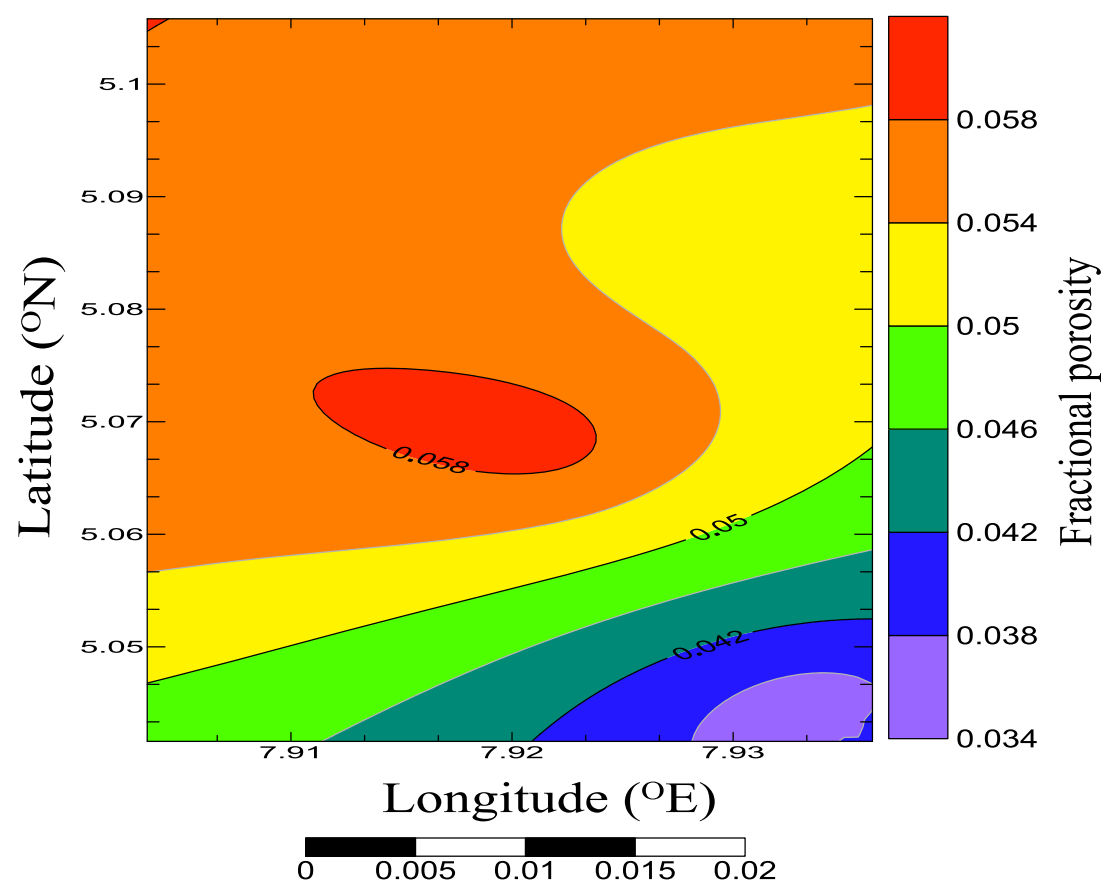

Fig. 7 Contour map showing the distribution of aquifer transmissivity

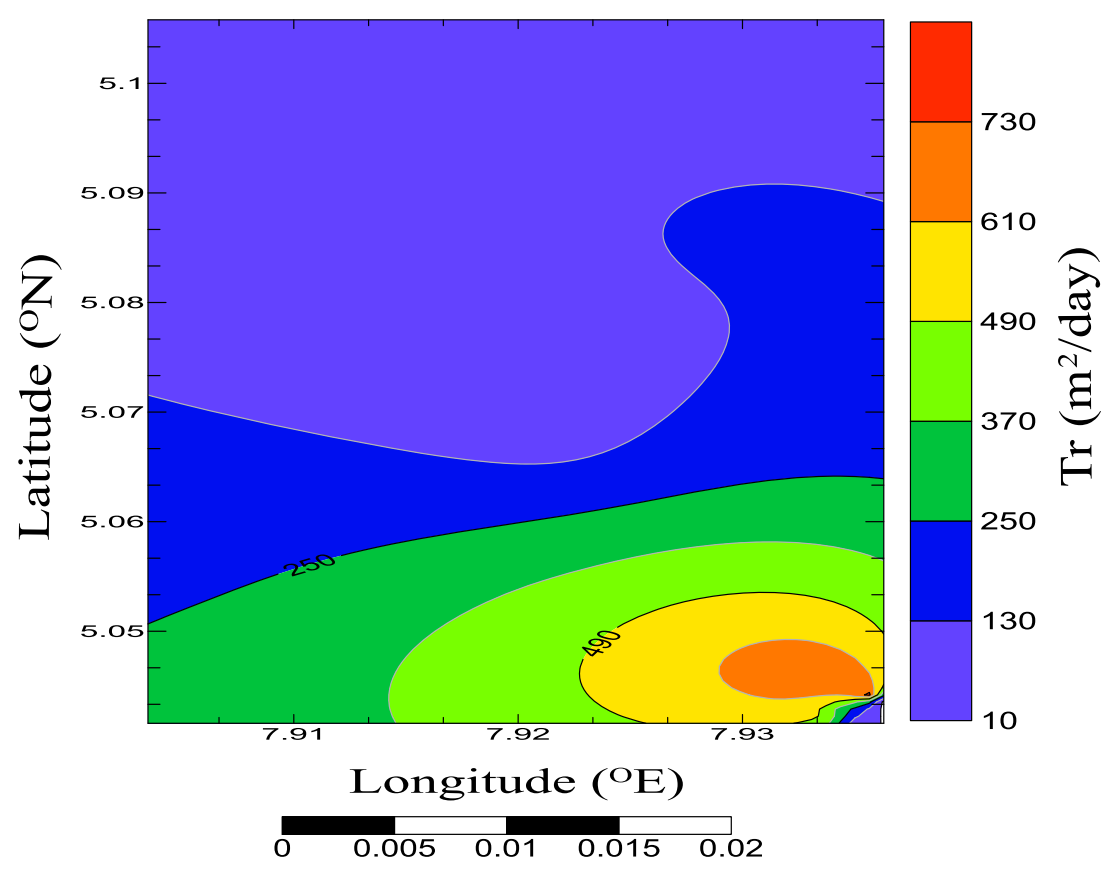

of the aquifers show that the entire subsurface studied is naturally endowed with groundwater. When wells are drilled to cut across reasonable section of the aquifer, the groundwater can be exploited and utilized. The closeness of the top of the aquifer such as VES 2, 4, 8, 11 and 13 and others with such thin overburden to the aquifer suggests that borehole within these locations are more susceptible to surface contamination. The uneven distribution of the geohydraulic parameters may due to uneven facies changes in geological formations. This study demonstrates the relevant of electrical resistivity survey in the investigation of the subsurface characteristics which have influence on groundwater repositories and the findings are valuable tools for groundwater management. 
Fig. 8 Contour map showing the distribution of longitudinal conductance

Fig. 9 Contour showing the variation of transverse resistance
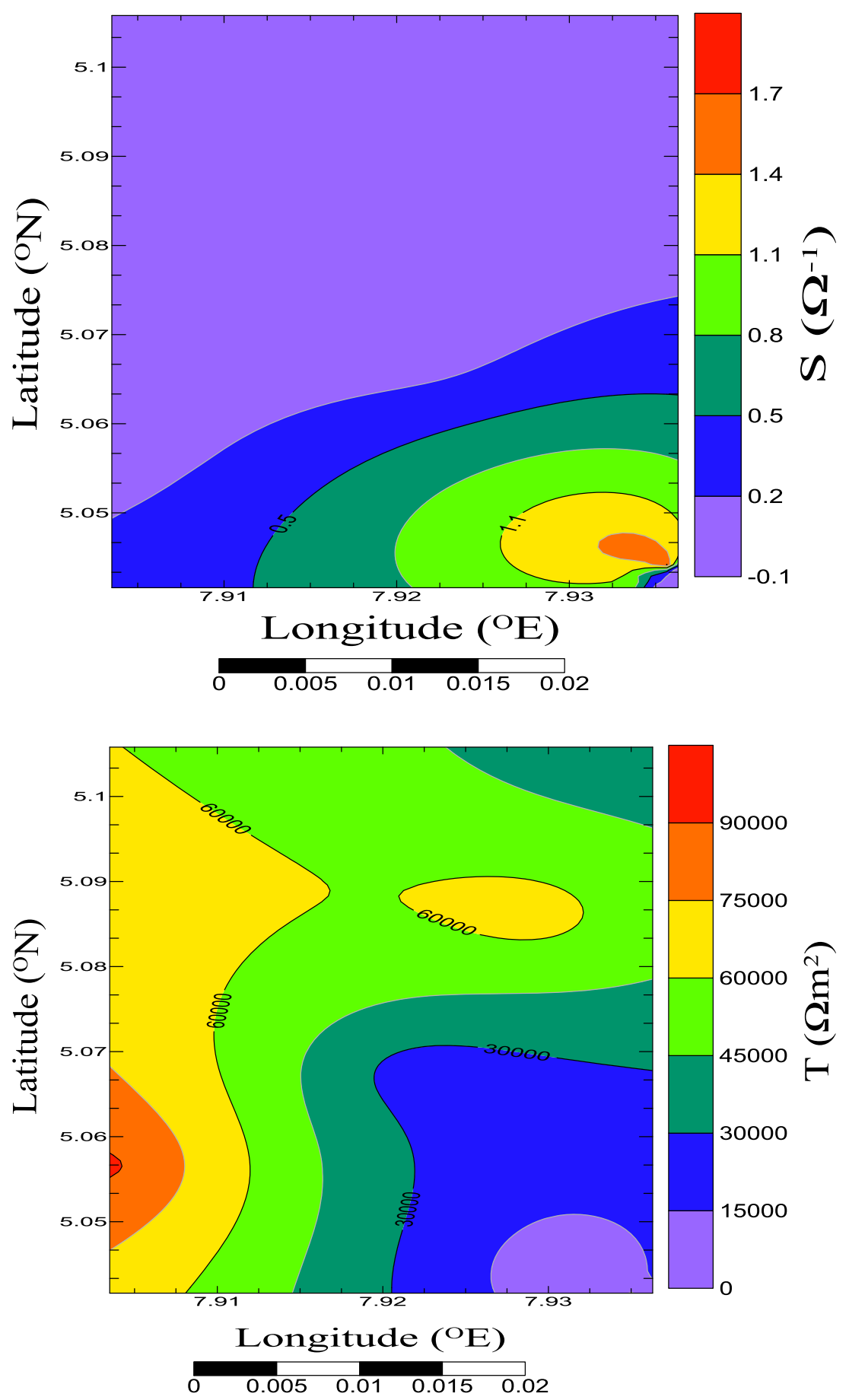

Table 3 Classification of soil resistivity in terms of corrosivity (Baeckmann and Schwenk 1975; Agunloye1984; Oladapo et al. 2004)

\begin{tabular}{ll}
\hline Soil resistivity $(\Omega \mathrm{m})$ & Soil corrosivity \\
\hline$<10$ & Very strongly corrosive (VSC) \\
$10-60$ & Moderately corrosive (MC) \\
$60-180$ & Slightly corrosive (SC) \\
$180 \geq$ & Non-corrosive (NC) \\
\hline
\end{tabular}

Open Access This article is distributed under the terms of the Creative Commons Attribution 4.0 International License (http:// creativecommons.org/licenses/by/4.0/), which permits unrestricted use, distribution, and reproduction in any medium, provided you give appropriate credit to the original author(s) and the source, provide a link to the Creative Commons license, and indicate if changes were made. 


\section{References}

Agunloye O (1984) Soil aggressivity along steel pipeline route at Ajaokuta, southwestern Nigeria. J Min Geol 21:97-101

Akpan FS, Etim ON, Akpan AE (2006) Geoelctrical investigation of groundwater potential in parts of EtimEkpo local government area, Akwa Ibom State. Nigeria J Phys 18:39-44

Archie GE (1942) The electrical resistivity logs as an aid in determining some reservoir characteristics. Trans Am Inst Mineral Metall Eng 146:54-62

Batayneh AT (2009) A hydrogeophysical model of the relationship between geoelectric and hydraulic parameters, Central Jordan. J Water Resour Prot 1:400-407

Baeckmann WV, Schwenk W (1975) Handbook of cathodic protection: the theory and practice of electrochemical corrosion protection technique. Cambridge Press

Chakravarthi V, Shankar GBK, Muralidharan D, Harinarayana T, Sundararajan N (2007) An integrated geophysical approach for imaging subbasalt sedimentary basins: case study of Jam river basin, India. Geophysics 72(6):141-147

Ebong DE, Akpan AE, Onwuegbuche AA (2014) Estimation of geohydraulic parameters from fractured shales and sandstone aquifers of Abi (Nigeria) using electrical resistivity and hydrogeologic measurements. J Afr Earth Sci 96:99-109

Edet AE, Worden RH (2009) Monitoring of the physical parameters and evaluation of the chemical composition of river and groundwater in Calabar (Southeastern Nigeria). Environ Monit Assess 157:243-258

Evans UF, George NJ, Akpan AE, Obot IB, Ikot AN (2010) A study of superficial sediments and aquifers in parts of Uyo local government area, Akwa Ibom State, Southern Nigeria, using electrical sounding method. E-J Chem 7(3):1018-1022

George NJ, Nathaniel EU, Etuk SE (2014) Assessment of economically accessible groundwater reserve and its protective capacity in eastern obolo local government area of Akwa Ibom state, Nigeria, using electrical resistivity method. ISRN Geophys 2014. doi: $10.1155 / 2014 / 578981$

George NJ, Ibuot JC, Obiora DN (2015a) Geoelectrohydraulic parameters of shallow sandy in Itu, Akwa Ibom State (Nigeria) using geoelectric and hydrogeological measurements. J Afr Earth Sci 110:52-63

George NJ, Emah JB, Ekong UN (2015b) Geohydrodynamic properties of hydrogeological units in parts of Niger Delta, southern Nigeria. J Afr Earth Sci 105(2015):55-63

George NJ, Akpan AE, Evans UF (2016a) Prediction of geohydraulic pore pressure gradient differentials for hydrodynamic assessment of hydrogeological units using geophysical and laboratory techniques: a case study of the coastal sector of Akwa Ibom State, Southern Nigeria. Arab J Geosci 9(4):1-13

George NJ, Akpan AE, Ekanem AM (2016b) Assessment of textural variation pattern and electrical conduction of economic and accessible quaternary hydrolithofacies via geoelectric and laboratory methods in SE Nigeria: a case study of select locations in Akwa Ibom state. J Geol Soc India 88:517-520

George NJ, Atat JG, Udoinyang IE, Akpan AE, George AM (2017a) Geophysical assessment of vulnerability of surficial aquifer: a case study of oil producing localities and Riverine areas in the coastal region of Akwa Ibom state, southern Nigeria. Curr Sci 113(3):430-438
George NJ, Ekanem AM, Ibanga JI, Udosen NI (2017b) Hydrodynamic implications of aquifer quality index (AQI) and flow zone indicator (FZI) in groundwater abstraction: a case study of coastal hydrolithofacies in South-eastern Nigeria. J Coast Conserv 20(4): $1-18$

Heigold PC, Gilkeson RH, Cartwright K, Reed PC (1979) Aquifer transmissivity from surficial electrical methods. Ground Water 17(4):338-345

Ibanga JI, George NJ (2016) Estimating geohydraulic parameters, protective strength, and corrosivity of hydrogeological units: a case study of ALSCON, Ikot Abasi, Southern Nigeria. Arab J Geosci 9(5):1-16

Jackson PD, Taylor-Smith D, Stanford PN (1978) Resistivity-porosity particles shape relationships for marine sands. Geophysics 43:1250-1268

Keller GV (1982) Electrical properties of rocks and minerals. In: Carmichael RS (ed) Handbook of Physical Properties of Rocks, vol 1. CRC Press, Boca Raton, pp 217-293

Keller CV, Frischnecht FC (1966) Electrical methods in geophysical prospecting. Pergamon Press, Oxford

Muchingami I, Hlatywayo DJ, Nel JM, Chuma C (2012) Electrical resistivity survey for groundwater investigations and shallow subsurface evaluation of the basaltic-greenstone formation of the urban Bulawayo aquifer. Phys Chem Earth 50-52(2012):44-51

Niwas S, Singhal DC (1981) Aquifer transmissivity of porous media from Dar-Zarrouk parameters in porous media. J Hydrol $82: 143-153$

Obiora DN, Ajala AE, Ibuot JC (2015) Evaluation of aquifer protective capacity of overburden unit and soil corrosivity in Makurdi, Benue State, Nigeria, using electrical resistivity method. J Earth Syst Sci 124(1):125-135

Offodile ME (1992) An approach to groundwater study and development in Nigeria. Mecon services Limited, Jos

Okiongbo KS, Mebine P (2015) Estimation of aquifer hydraulic parameters from geoelectrical method - a case study of Yenagoa and environs, Southern Nigeria. Arab J Geosci 8(8):6085-6093

Oladapo MI, Mohammed MZ, Adeoye OO, Adetola OO (2004) Geoelectric investigation of the Ondo State Housing Corporation Estate; Ijapo, Akure, southwestern Nigeria. J Min Geol 40(1):41-48

Orellana E, Mooney H (1966) Master tables and curves for VES over layered structures. Interciencia, Madrid

Ugbaja AN, Edet AE (2004) Groundwater pollution near shallow waste dumps in southern calabar south-eastern Nigeria. Global J Geol Sci 2(2):199-206

Zohdy AAR (1965) The auxiliary point method of electrical sounding interpretation and its relationship to the Dar-Zarrouk parameters. Geophysics 30:644-660

Zohdy AAR, Eaton GP, Mabey DR (1974) Application of surface geophysics to groundwater investigation. USGS Techniques of water resources investigations, Book 2, Chapter D1

\section{Publisher's Note}

Springer Nature remains neutral with regard to jurisdictional claims in published maps and institutional affiliations. 